\title{
Loperamide Hydrochloride
}

National Cancer Institute

\section{Source}

National Cancer Institute. Loperamide Hydrochloride. NCI Thesaurus. Code C1584.

The hydrochloride salt form of loperamide, a synthetic, piperidine derivative and opioid agonist with antidiarrheal activity. Loperamide acts on the mu-receptors in the intestinal mucosa. This leads to a decrease in gastrointestinal motility by decreasing the circular and long itudinal smooth muscle activity of the intestinal wall. This slows intestinal transit and allows for more water and electrolyte absorption from the intestines. Loperamide is not significantly absorbed from the gut and does not cross the blood-brain barrier.

Therefore it has no central nervous system effects. 